\title{
Pengelolaan Feces Sebagai Pencegahan Penularan Covid-19
}

\author{
Fecal Management as a Prevention of Transmission of Covid-19 \\ ${ }^{1 *}$ Andik Setiyono, ${ }^{2)}$ Joni, ${ }^{3)}$ Trisna Wijaya, ${ }^{4)}$ Rinaldi Rizal Putra \\ ${ }^{1)}$ Jurusan Kesehatan Masyarakat Fakultas Ilmu Kesehatan \\ ${ }^{2,3)}$ Jurusan Ekonomi Syariah Fakultas Agama Islam \\ 4) Jurusan Pendidikan Biologi Fakultas Keguruan dan Ilmu Pendidikan \\ Universitas Siliwangi, Jalan Siliwangi No. 24 Kota Tasikmalaya \\ *email: a.setiyono@yahoo.com
}

DOI:

10.30595/jppm.v5i1.9225

Histori Artikel:

Diajukan:

$13 / 12 / 2020$

Diterima:

$10 / 01 / 2022$

Diterbitkan:

$18 / 02 / 2022$

\begin{abstract}
ABSTRAK
Isu kesehatan di tengah pandemi Covid-19 selalu menjadi bagian yang terus diperhatikan, mengingat semua negara dan masyarakat dunia berusaha untuk memutus rantai penyebaran Covd-19 ini. Salah satu upaya yang dapat dilakukan adalah dengan meningkatkan taraf kesehatan masyarakat, selain membiasakan menggunakan masker dan menjaga jarak, adalah dengan pengelolaan limbah domestik (khususnya feses) yang baik dan tepat. Kecamatan Tawang Kota Tasikmalaya menjadi salah satu kecamatan yang memiliki permasalahan yang sebagian rumah tangganya tidak memiliki pengelolaan feses yang baik. Pendekatan yang digunakan dalam pelaksanaa kegiatan ini adalah partisipatory rural appraisal (PRA), dengan menggunakan metode pelatihan, brainstorming, dan demonstrasi. Dalam pelaksanaannya, masyarakat diberikan edukasi mengenai prinsip pengelolaan feses yang baik tepat, sebagai salah stau pendukung pencegahan penularan Covid-19. Hasil yang diperoleh dari kegiatan pengabdian pada masyarakat ini adalah masyarakat memiliki harapan besar dalam peningkatan sanitasi dan akses kebersihan. Salah satu indikatornya adalah didukung dengan kesiapan warga masyarakat untuk tidak membuang limbah feses ke sungai, dan dialihkan ke septic tank komunal.
\end{abstract}

Kata kunci: Pengelolaan Feses; Covid-19; Open Defecation Free

\begin{abstract}
Health issues during the Covid-19 pandemic have always been a part that continues to be paid attention to, considering that all countries and the world community are trying to break the chain of spreading Covid-19. One of the efforts that can be done is to improve the level of public health and get used to wearing masks and maintaining distance by proper and proper management of domestic waste (especially feces). Tawang Subdistrict, Tasikmalaya City, is one of the districts with problems where some of the households do not have good fecal management. The approach used in implementing this activity is participatory rural appraisal (PRA), using training, brainstorming, and demonstration methods. In its implementation, the public is given education on the principles of proper management of good stool, as one of the supporters of preventing the transmission of Covid19. The community service activity results are that the community has high hopes for improving sanitation and access to hygiene. One indicator is supported by community members' readiness not to dispose offecal waste into the river and divert it to communal septic tanks.
\end{abstract}

Keywords: Fecal Management; Covid-19; Open Defecation Free 


\section{PENDAHULUAN}

Pandemi coronavirus disease 2019 (Covid-19) yang pertama kali muncul di Provinsi Hubei, Tiongkok telah menyebar dengan sangat masif ke lebih dari 165 negara dalam kurun waktu sekitar 3 bulan (Amirian 2020), sehingga ditetapkan sebagai pandemi global (Arslan, Xu, and El-din 2020). Indonesia termasuk ke dalam negara yang terdampak Covid-19, sehingga menyebabkan berbagai sendi kehidupan terganggu. Tidak hanya kesehatan, sendi lain dari kehidupan lain yang terganggu dengan adanya pandemi Covid-19 ini antara lain ekonomi dan bisnis (Hanoatubun 2020; Sakri 2020; Taufik and Ayuningtyas 2020), serta bidang pendidikan (Aji 2020).

Berbagai upaya dilakukan oleh berbagai negara agar mata rantai penyebaran Covid-19 ini terputus, antara lain dengan menerapkan kebiasaan memakai masker, penerapan pembatasan social berskala besar (PSBB) (Nasruddin and Haq 2020; Ristyawati 2020; Thorik 2020), peningkatan taraf kesehatan, dan sanitasi lingkungan (Heller, Mota, and Greco 2020). Dengan berbagai langkah tersebut, diharapkan penyebaran Covid-19 dapat terhenti sehingga kehidupan masyarakat dapat kembali berjalan normal.

Salah satu upaya yang masih perlu digiatkan dalam penanganan dan pencegahan penularan wabah Covid-19 adalah sanitasi dan pengelolaan limbah domestik (khususnya feses). Berdasarkan laporan yang dikemukakan oleh Xiao et al. (2020), dan Arslan et al. (2020), bahwa materi genetik dari coronavirus penyebab Covid-19 telah terdeteksi dalam feses, urin, dan jarum suntik dari pasien yang terpapar Covid-19. Namun, hal ini masih menjadi perdebatan pada ahli virologi, mengingat apakah virus yang ditemukan dalam feses pasien Covid-19 tersebut dalam menjadi sumber penularan baru selain dari droplet.

Pengelolaan feses di sebagian besar negara berkembang masih belum memenuhi persyaratan dasar kesehatan lingkungan, termasuk di Indonesia. Sebagian besar masyarakat pada dasarnya telah memiliki fasilitas sanitasi dan MCK di rumahnya, namun masih membuang limbah feses ke sungai (Rahmadani and Ridlo 2020). Ketiadaan fasilitas pengelolaan feses/tinja di sebagian rumah menyebabkan sungai menjadi tempat pembuangan feses, sehingga keasrian dan nilai guna air sungai menjadi berkurang.

Hal itu juga yang terjadi di sebagian pemukiman yang berada di Kota Tasikmalaya, yang memanfaatkan kolam dan sungai sebagai tempat menampung dan pembuangan feses. Perilaku tersebut memberi kontribusi terhadap pencemaran air tanah oleh bakteri yang berasal dari feces. Perilaku lainnya dalam pembuangan feces di masyarakat adalah dengan memanfaatkan cubluk (sejenis konstruksi septic tank sederhana) yang masih berpotensi mencemari air tanah. Desain cubluk yang tidak memisahkan feces dengan air penggelontor serta konstruksinya yang masih sederhana menjadi penyebab cubluk tidak dipersyaratkan sebagai fasilitas pengelolaan feces. Pembuangan feces lain yang masih dilakukan masyarakat adalah membuang feces ke sungai melalui saluran perpipaan.

Perilaku tersebut terutama dilakukan masyarakat yang berada di daerah aliran sungai. Potensi pencemaran air permukaan sangat besar sehingga kualitas air sungai merosot dan tidak layak digunakan sebagai air baku di unit PDAM.

Akses sanitasi yang layak merupakan salah satu pondasi inti dari masyarakat yang sehat. Sanitasi berhubungan dengan kesehatan lingkungan yang mempengaruhi derajat kesehatan masyarakat. Pemenuhan sarana sanitasi di rumah tangga sangat terkait dengan tingkat pengetahuan masyarakat. Tingkat pendapatan tidak dapat diabaikan yang juga memberikan kontribusi pemenuhan sarana sanitasi di rumah tangga.

Data Perilaku Hidup Bersih dan Sehat (PHBS) Kota Tasikmalaya menunjukkan $37,5 \%$ masyarakat tidak memiliki jamban keluarga, jarak cubluk dengan sumber air bersih $<10$ meter masih menjadi masalah (Bappeda, 2016). Kepemilikan jamban yang sehat bagi masyarakat masih $81,70 \%$ (Dinkes Kota Tasikmalaya, 2015). Artinya masyarakat yang memiliki jamban belum tentu memenuhi syarat. Contohnya adalah tempat pembuangan masih ke sungai 25,3\%, cubluk 24,3\%, kolam 9,8\% (Dinkes Kota Tasikmalaya, 2015). 
Kemudian, berdasarkan hasil observasi dan wawancara dengan salah satu mitra pelaksana, diketahui bahwa sebagian besar rumah tangga di wilayahnya belum memiliki fasilitas pembuangan limbah feses, sehingga pembuangan dilakukan secara langsung melalui aliran sungai. Hal itu dikarenakan desain setiap rumah tidak mendukung untuk kepemilikan septic tank secara pribadi. Selain itu, faktor kepemilikan lahan pribadi untuk pembuatan septic tank pun menjadi kendala karena sempitnya lahan rumah yang mumpuni untuk dibuat septic tank.

Kepemilikan jamban sehat dengan sistem pembuangan septic tank masih sangat terbatas. Kondisi lain perilaku masyarakat yang masih membuang feses di sembarang tempat memperparah pencemaran air tanah. Cakupan air bersih yang masih dibawah target menyebabkan masyarakat mendapatkan air yang tidak memenuhi syarat air bersih. Pemenuhan kebutuhan air bersih masyarakat yang utama berasal dari air sumur gali dangkal yang secara mandiri masyarakat berusaha memenuhinya. Sumur gali dangkal yang sangat berpotensi tercemar terutama berasal dari feces yang dibuang sembarangan menjadi penyebab air sumur gali tercemar oleh bakteri yang berasal dari feces. Beberapa sebab tersebut bisa menjadi media penyebaran Covid-19.

Berdasarkan latar belakang tersebut, maka tujuan dari kegiatan ini adalah untuk memberikan pengetahuan dan pengalaman kepada masyarakat mengenai pengelolaan feses yang tepat dengan guna mencegah penularan Covid-19.

\section{METODE}

Untuk mencapai tujuan pengabdian pada masyarakat tentang Pengelolaan Feces sebagai Pencegahan Penularan Covid-19, metode yang digunakan adalah pendidikan masyarakat. Kemudian, pendekatan yang digunakan dalam pelaksanaan kegiatan ini adalah Partisipatory Rural Appraisal (PRA). Pendekatan ini merupakan pendekatan dalam merumuskan perencanaan dan kebijakan di wilayah pedesaan dengan cara melibatkan masyarakat seefektif mungkin (Supriatna, 2014). Melalui pendekatan PRA ini, masyarakat pedesaaan dilibatkan secara aktif dan efektif, serta dapat dicapainya kesuaian dan ketepatgunaan program bagi masyarakat, sehingga keberlanjutkan program lebih terjamin.

Siklus dan tahapan pendekatan PRA yang digunakan antara lain pengenalan masalah/kebutuhan dan potensi wilayah secara umum; perumusan masalah dan penetapan prioritas masalah; identifikasi alternatif pemecahan masalah; pemilihan alternatif pemecahan masalah sesuai dengan kemampuan dan sumber daya yang tersedia; perencanaan penerapan gagasan; penyajian rencana kegiatan; pelaksanaan dan pengorganisasian masyarakat sesuai dengan kebutuhan dan tingkat perkembangan masyarakat; pemantauan dan pengarahan; dan evaluasi serta rencana tindak lanjut (Supriatna, 2014; Soehendera, 2001). Siklus dan tahapan pendekatan PRA tersebut, dibagi ke dalam tiga tahapan, yaitu tahapan awal (persiapan), tahapan inti kegiatan, dan tahapan penutup.

Tahapan awal kegiatan dilakukan dengan melakukan analisis situasi terlebih dahulu. Analisis situasi ditempuh dengan cara melakukan observasi awal dan wawancara kepada pihak terkait (mitra), untuk mengetahui permasalahan yang timbul pada mitra. Apabila permasalahan telah terhimpun, kemudian menetapkan priortas masalah yang akan dipececahkan bersama mitra.

Tahapan inti kegiatan dilakukan dengan melakukan penyuluhan kepada masyarakat mengenai pengelolaan feses berbasis rumah tangga dan potensi penularan Covid-19 melalui feses. Pada tahapan ini juga, dilakukan dengar pendapat dari masyarakat mengenai pengelolaan feses. Pada kegiatan inti ini, diakhiri dengan pemberian hibah asset berupa septic tank komunal sesuai standar kesehatan.

Terakhir, yaitu tahapan penutup dilakukan dengan monitoring dan evaluasi hasil pelaksanaan pengabdian. Untuk melihat kemajuan sebelum dan setelah dilakukan kegiatan penyuluhan/Pendidikan masyarakat, responden diberikan soal berkaitan dengan materi yang diberikan. Soal yang diberikan berupa tes pilihan majemuk dengan jumlah 7 soal pada kategori $\mathrm{C} 1$. 


\section{HASIL DAN PEMBAHASAN}

Dasar pemikiran dari kegiatan adalah adanya potensi penularan Covid-19 melalui feses serta pengelolaan feses di masyarakat pada umumnya belum memenuhi syarat kesehatan yaitu pembuangan hanya melalui septic tank. Kegiatan PPM ini dibagi di dua lokasi, yaitu Pondok Pesantren As-Salam Kelurahan Kahuripan dan masyarakat RW 01 Tawangkulon Kelurahan Tawangsari Kecamatan Tawang. Penentuan dua lokasi mewakili kelompok masyarakat yang ada di Kecamatan Tawang, juga karena keterbatasan alokasi anggaran yg dimiliki.

Pelaksanaan kegiatan dibagi dua jenis, yaitu penyampaian materi cara pengelolaan feses agar mampu mencegah pencemaran air dan tanah oleh bakteri khususnya potensi virus Corona saat pandemi dan penyerahan dua unit septic tank kapasitas masing-masing 2000 liter kepada perwakilan kelompok masyarakat/pimpinan pesantren sebagai tindak lanjut dan sebagai stimulan sarana di kelompok masyarakat sasaran. Waktu pelaksanaan dibagi dalam dua waktu yang berbeda, dimulai hari Jum'at tanggal 30 Oktober 2020 dilaksanakan di Pesantren As Salam yang diikuti pimpinan pesantren serta jamaah pesantren sekitar 60 orang (Gambar 1). Kegiatan dimulai sekitar jam 09.00 diawali pembukaan oleh pimpinan pesantren dan selanjutnya dilaksanakan penjelasan tentang pengelolaan feses serta kaitannya terhadap pencegahan penularan Covid-19.

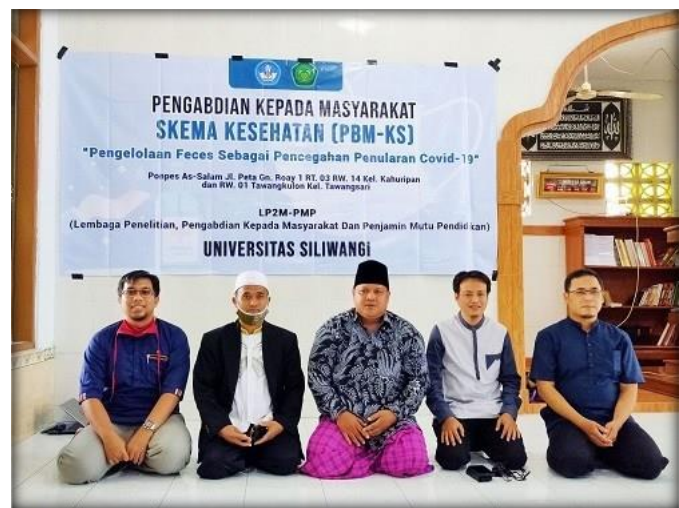

Gambar 1. Pelaksanaan kegiatan pengabdian di Pondok Pesantren As-Salam
Penyampaian materi berlangsung sekitar 60 menit dan dilanjutkan sesi tanya jawab dengan peserta. Di dalam pelaksanaan kegiatan tersebut tampak peserta cukup antusias memperhatikan materi yang disampaikan. Respon berupa pertanyaan dari peserta juga cukup baik. Kegiatan berikutnya yaitu penyerahan sarana septic tank kepada pimpinan pesantren As Salam (Gambar 2). Pimpinan pesantren sangat mengapresiasi kegiatan yang diadakan dan akan segera memanfaatkan sarana septic tank dalam waktu dekat. Lahan untuk peletakan septic tank sudah disiapkan sekitar pesantren.

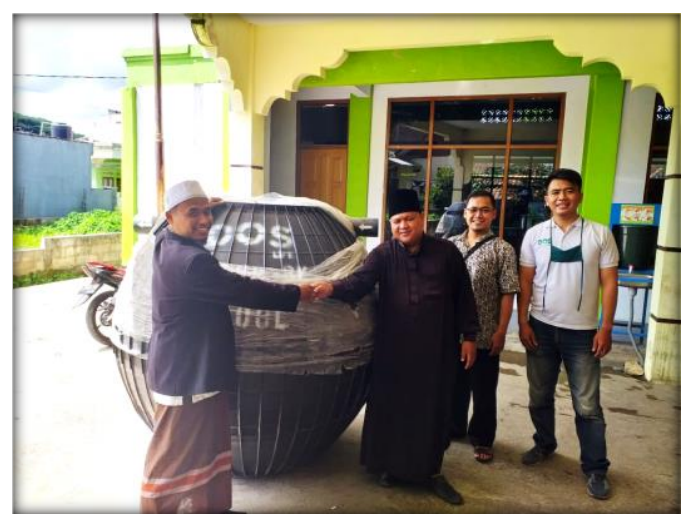

Gambar 2. Serah terima aset berupa satu unit septic tank kepada pimpinan Pondok Pesantren As-Salam

Pelaksanaan di lokasi kedua yaitu RW. 01 Tawangkulon Kelurahan Tawangsari dilaksanakan pada hari Sabtu 14 November 2020. Peserta di lokasi kedua adalah perwakilan masyarakat dan tokoh masyarakat serta ketua RW 01 (Gambar 3). Kegiatan dimulai pukul 13.00 di aula RW 01 Tawangkulon. Dimulai dengan pembukaan oleh Ketua RW 01 dan selanjutnya penyampaian materi tentang pengelolaan feses serta kaitannya terhadap pencegahan penularan Covid-19. Penyampaian materi berlangsung sekitar 60 menit dan dilanjutkan sesi tanya jawab dengan peserta. 


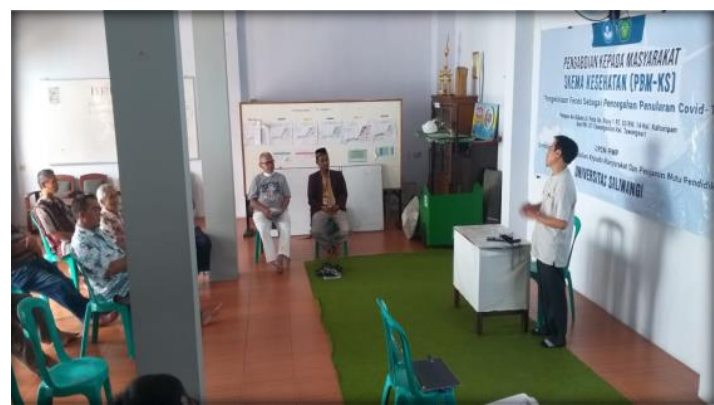

Gambar 3. Pelaksanaan kegiatan pengabdian di RW. 01 Tawangkulon

Dalam pelaksanaan kegiatan tersebut tampak peserta cukup antusias memperhatikan materi yang disampaikan. Respon berupa pertanyaan dari peserta juga cukup baik. Kegiatan berikutnya yaitu penyerahan sarana septic tank kepada Ketua RW 01 (Gambar 4). Dalam sambutannya Ketua RW 01 sangat antuasias dan mengapresiasi kegiatan tersebut dan akan segera menindaklanjuti pembangunan septic tank pada lahan yang sudah disiapkan. Kesiapan warga sudah terbangun komitmen untuk bersama-sama memindahkan saluran pembuangan feses ke septic tank. Harapan dari kegiatan ini dari penyampaian materi serta pemberian sarana septic tank sebagai stimulan mampu mendorong perubahan perilaku masyarakat untuk mengelola fesesnya secara mandiri ke tempat pembuangan yang sehat yaitu septic tank.

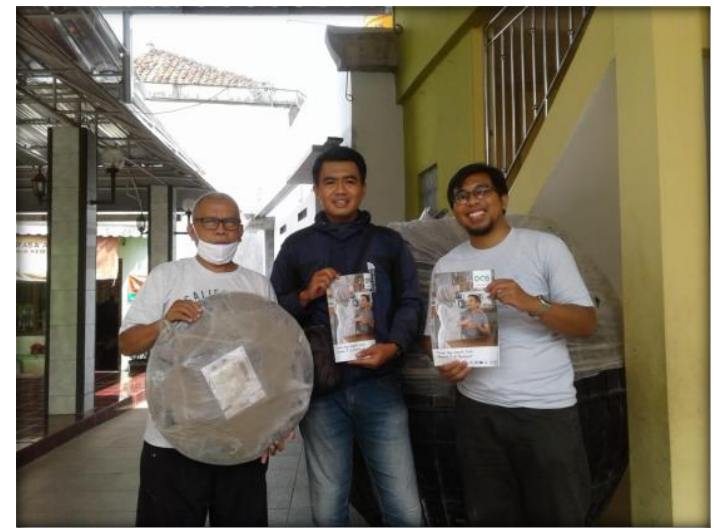

Gambar 4. Serah terima aset berupa satu unit septic tank kepada mitra RW. 01 Tawangkulon

Berikutnya, hasil pretest dan posttest yang diuji menggunakan Uji Wilcoxon, diperoleh $p$ value 0,001 lebih kecil dari alpha 0,05 sehingga disimpulkan ada perbedaan nilai pretest dengan posttest peserta pengabdian kepada masyarakat terkait pengelolaan feces dalam pencegahan penularan Covid-19. Dari semua peserta yang mengikuti kegiatan, nilai posttest lebih tinggi daripada pretest. Hal ini menunjukkan ada peningkatan pengetahuan peserta terkait pengelolaan feses dalam pencegahan penularan Covid-19.

Hasil analisis tingkat kepuasan masayarakat peserta pengabdian dosen terbagi dalam 7 indikator. Indikator pertama adalah terkait waktu pelaksanaan kegiatan menunjukkan $42,87 \%$ peserta PPM menyatakan sangat tepat, $28,57 \%$ menyatakan tepat, $28,56 \%$ menyatakan cukup tepat.

Indikator kedua berdasar tempat pelaksanaan kegiatan menunjukkan 57,14\% peserta menyatakan nyaman, $21,43 \%$ peserta menyatakan sangat nyaman, dan 21,43\% menyatakan cukup nyaman. Berikutnya indikator ketiga terkait lamanya waktu pelaksanaan kegiatan PPM menunjukkan 50\% peserta menyatakan sudah sesuai, sebanyak $35,71 \%$ menyatakan cukup sesuai, $7,14 \%$ menyatakan sangat sesuai dan $7,14 \%$ menyatakan kurang sesuai.

Indikator keempat tentang penyampaian materi yaitu sebanyak $64,28 \%$ peserta menyatakan sangat jelas, $21,43 \%$ menyatakan jelas dan 14,28\% menyatakan cukup jelas. Indikator kelima terkait media yang digunakan dalam penyampaian materi PPM didapatkan $42,86 \%$ peserta menyatakan baik, $28,57 \%$ peserta menyatakan sangat baik dan $28,57 \%$ menyatakan cukup baik.

Indikator keenam tentang audio yang digunakan dalam penyampaian materi PPM didapatkan $42,86 \%$ peserta menyatakan baik, sebanyak $35,71 \%$ menyatakan cukup baik dan $21,43 \%$ menyatakan sangat baik. Terakhir, indikator ketujuh terkait pemberian bantuan stimulan sarana septic tank komunal kepada kelompok masyarakat, didapatkan 50\% menyatakan puas, $28,57 \%$ menyatakan sangat puas, dan $21,43 \%$ menyatakan cukup puas. Respon berupa saran peserta PPM adalah agar masyarakat diperhatikan terkait stimulan sarana septic tank dengan jumlah bantuan lebih luas menjangkau sasaran masyarakat. 


\section{SIMPULAN}

Berdasarkan hasil pelatihan yang telah dilaksanakan, dapat disimpulkan bahwa masyarakat memiliki harapan besar dalam peningkatan sanitasi dan akses kebersihan. Salah satu indikatornya adalah didukung dengan kesiapan warga masyarakat untuk tidak membuang limbah feses ke sungai, dan dialihkan ke septic tank komunal.

\section{DAFTAR PUSTAKA}

Aji, Rizkon Halal Syah. 2020. "Dampak Covid19 Pada Pendidikan Di Indonesia: Sekolah, Keterampilan, Dan Proses Pembelajaran." SALAM: Jurnal Sosial Dan Budaya Syar-I 7(5):395-402.

Amirian, E. Susan. 2020. "Potential Fecal Transmission of SARS-CoV-2: Current Evidence and Implications for Public Health." International Journal of Infectious Diseases 95:363-70.

Arslan, Muhammad, Bin $\mathrm{Xu}$, and Mohamed Gamal El-din. 2020. "Transmission of SARS-CoV-2 via Fecal-Oral and Aerosols - Borne Routes: Environmental Dynamics and Implications for Wastewater Management in Underprivileged Societies." Science of the Total Environment 743:1-8.

Hanoatubun, Silpa. 2020. "Dampak Pandemi COVID-19 Terhadap Perekonomian Indonesia." EduPsyCouns Journal 2(1):146-15.

Heller, Léo, César R. Mota, and Dirceu B. Greco. 2020. "COVID-19 Faecal-Oral Transmission: Are We Asking The Right Questions?" Science of the Total Environment 729:1-3.

Nasruddin, Rindam, and Islamul Haq. 2020. "Pembatasan Sosial Berskala Besar (PSBB) Dan Masyarakat Berpenghasilan Rendah." SALAM: Jurnal Sosial Dan Budaya Syar-I 7(7):639-48.

Rahmadani, Rizky Dwi, and Ilham Akhsanu Ridlo. 2020. "Perilaku Masyarakat Dalam Pembuangan Tinja Ke Sungai Di Kelurahan Rangkah, Surabaya." Jurnal Promkes: The Indonesian Journal of
Health Promotion and Health Education 8(1):87-98.

Ristyawati, Aprista. 2020. "Efektifitas Kebijakan Pembatasan Sosial Berskala Besar Dalam Masa Pandemi Corona Virus 2019 Oleh Pemerintah Sesuai Amanat UUD NRI Tahun 1945." Administrative Law and Governance Journal 3(2):24049.

Sakri, Diding. 2020. "Menakar Dampak Pandemi COVID-19 Terhadap Perekonomian Daerah." CSIS Commentaries DMRU-088-ID (8 Juli):110.

Soehendera, D. (2001). "P.R.A. - Participatory Research Appraisal dalam Pelaksanaan Pengabdian kepada Masyarakat, Modul Latihan". Antropologi Indonesia, 66: 100 $-104$.

Supriatna, A. (2014). "Relevansi Metode Participatory Rural Appraisal dalam Mendukung Implementasi UndangUndang Pemerintah Desa”. Jurnal Lingkar Widyaiswara, 1(1): 39 - 45.

Taufik, and Eka Avianti Ayuningtyas. 2020. "Dampak Pandemi Covid-19 Terhadap Bisnis Dan Eksistensi Platform Online." Jurnal Pengembangan Wiraswasta 22(01):21-32.

Thorik, Sylvia Hasanah. 2020. "Efektivitas Pembatasan Sosial Berskala Besar Di Indonesia Dalam Penanggulangan Pandemi Covid-19." Adalah: Buletin Hukum Dan Keadilan 4(1):115-20.

Xiao, Fei, Jing Sun, Yonghao Xu, Fang Li, Xiaofang Huang, Heying Li, Jingxian Zhao, Jicheng Huang, and Jincun Zhao. 2020. "Infectious SARS-CoV-2 in Feces of Patient with Severe COVID-19." Emerging Infectious Diseases 26(8):1920-22. 